\title{
INFLUENCE OF CSN3, LGB, PRL, GH, TG5 GENES ALLELES ON DAIRY PRODUCTIVITY AND ENERGY VALUE OF COW'S MILK
}

\author{
Evgeny O. Krupin ${ }^{1 *}$, Shamil K. Shakirov² \\ ${ }^{1 *}$ Tatar Scientific Research Institute of Agriculture \\ ${ }^{2}$ FRC Kazan Scientific Center, Russian Academy of Sciences, Kazan, Russia \\ evgeny.krupin@gmail.com
}

\begin{abstract}
https://doi.org/10.34302/2019.11.4.9
Article history:

Received:

1 August 2019

Accepted:

1 November 2019

\section{Keywords:}

Milk production;

Fat;

Protein;

Genotype;

Cow

ABSTRACT

The aim of our research was to study the dependence of Kholmogorsk breed dairy cows' productivity on polymorphism of kappa-casein (CSN3), betalactoglobulin (LGB), prolactin (PRL), somatotropin (GH), thyroglobulin (TG5) genes. It was found that B allele (BB genotype) of PRL gene caused maximum increase in milk production (19.7\%). Maximum increase in milk productivity $(15.0 \%, \mathrm{P}<0.001)$, was found at L allele (LL genotype) of GH gene. Significant increases in the presence of $\mathrm{A}$ and $\mathrm{B}$ alleles with AA $(14.3 \%)$ and $\mathrm{BB}(12.7 \%)$ genotypes of CSN3 and LGB genes were detected. The maximum increase in fat mass fraction $(0.22 \%)$ in milk was found at ABL homozygous genotype of PRL gene, while significant increase of fat content was detected at $\mathrm{C}$ allele (CC genotype) of TG5 gene $(0.15 \%, \mathrm{P}$ $<0.05$ ). The maximum increase of protein mass fraction at $\mathrm{B}$ allele (BB genotype) of PRL gene $(0.11 \%)$ was detected. The maximum increase in milk protein was found at $\mathrm{B}$ and $\mathrm{L}$ alleles (BB and LL genotypes) of LGB and GH genes ( $0.06 \%$ with $\mathrm{P}<0.01$ and $\mathrm{P}<0.001$, respectively). Analysis of milk energy value showed that $\mathrm{A}$ and $\mathrm{B}$ alleles and $\mathrm{AA}(2.80 \mathrm{MJ} / \mathrm{kg})$ and $\mathrm{BB}(2.80 \mathrm{MJ} / \mathrm{kg})$ genotypes of CSN3 gene and BB genotype of LGB $(2,82$ $\mathrm{MJ} / \mathrm{kg}$ ) and PRL genes $(2.93 \mathrm{MJ} / \mathrm{kg}$ ), as well as the T allele and TT genotype for the TG5 gene $(3.17 \mathrm{MJ} / \mathrm{kg})$ are associated with this indicator.
\end{abstract}

\section{Introduction}

All over the world, cow farming mainly targets milk production. The average milk production level of cows differs between regions, partly due to different cow genetics (Perišić et al, 2011). Cow genetics basically determines the potential of their milk production, in fact - the amount of milk received from animals. It is known that the level of milk productivity is a polygenic trait controlled by various genetic loci (Dybus et al, 2004; Singh et al, 2014), some of which are already known (Singh et al, 2014; Khatami et al, 2005), and some are only classified as candidate genes (Viale et al, 2017). Based on literature data, the following economically valuable traits gene loci were selected for our work: kappa-casein (CSN3) (Chasovshchikova et al, 2017), beta-lactoglobulin (LGB) (Di Gregorio et al, 2017), prolactin (PRL) (Chasovshchikova et al, 2017), somatotropin (GH) (Akyuz et al, 2015; Metin Kiyici et al, 2019), thyroglobulin (TG5) (Zhang et al, 2015).

On the other hand, realization of a dairy cow as its genetically determined potential for milk production depends on the technology of keeping and growing, as well as the feeding programs used. In general, the increase in the economic efficiency of livestock production is closely related to the intensity of livestock reproduction and the terms of 
the productive use of animals, which largely depends on the level of milk productivity (Turenkova \& Vasilieva, 2014). So, the fundamental factor ensuring stable and profitable dairy cattle breeding is the introduction of technological innovations that reduce losses by improving the health and productivity of the herd. Therefore, there is an acute issue of reassessing the available genetic resources of dairy cattle breeding, both of individual breeding animals, and of breeds, and types in general. The severity of the problem is due to the fact that all the work carried out by livestock breeders on Holsteinization is associated with an increase in the amount of milk received from animals, and it is not carried out in isolation, but against the background of changing in technology as a whole and of introduction of various innovations in feed production and feeding (Furaeva, 2013).

It is well known and repeatedly proven that the composition of milk depends on the technology of feeding in general, which can be used to control the content of the mass fraction of fat in milk and the fatty acid composition of milk fat itself. In addition, feed strategies have been developed to regulate the content of the mass fraction of protein in milk (Chilliard et al, 2007).

The insufficient production of high-quality feed and their inefficient use leads to a decrease in milk productivity and high feed costs per unit of production and, ultimately, has a negative impact on the economy of the entire production (Giniyatullin, 2016).

As world experience shows, the achievement of success in animal husbandry in general and in increasing the milk production of animals and reducing the cost of production of animal products in particular, only $30 \ldots 35 \%$ determined by achievements in breeding and genetics, but on $50 \ldots$ $60 \%$ they depends on feeding. The organization of a balanced feeding of dairy cows in different physiological periods determines their high milk productivity, and, consequently, an increase in the production of livestock products. In addition, the balanced feeding of animals is one of the main factors ensuring the effectiveness of breeding, and acts as a fundamental element of a set of measures to increase the milk productivity of animals, improve existing breeds and types (Maslyuk \& Tokareva, 2018).

So, the aim of our work was to study changes in the productive qualities of dairy cows depending on the polymorphism of responsible for the phenotypic manifestation of economically valuable traits genes. To solve this problem we established genotypes of dairy cows at the loci of genes studied and we analyzed the dynamics of cow's milk productivity and mass fractions of fat and protein in milk obtained from them and calculation of the energy value of milk from different genotypes. Also we have determined dependences of milk productivity, the content of the mass fraction of fat and protein in milk and the energy value of milk at these genotypes.

\section{Materials and methods}

Population studied, sample size and animal feeding

All studies were performed using dairy cows of the Tatarstan type of Kholmogorsk breed. Experimental animals were kept on a leash. For the formation of one miniature herd of 81 experimental animals, animals were allocated to the group, which is an independent production unit. The composition of this group was a reduced copy of the herd on which the study was conducted. When forming the miniature herd, the age of the animal and the level of their productivity were taken into account. The relative heterogeneity of the miniature herd allowed us to assess the influence of the studied factors under conditions, approximated to production.

The main diet of all dairy cows consisted of roughage (1.5 kg of alfalfa hay), succulent feed ( 8.0 $\mathrm{kg}$ of alfalfa haylage; $9.0 \mathrm{~kg}$ of grass mix haylage; $12.0 \mathrm{~kg}$ of corn silage) and concentrated feed (6, 0 $\mathrm{kg}$ of mixed feed for dairy cows; $2.0 \mathrm{~kg}$ of corn grain; $1.0 \mathrm{~kg}$ of beer dry draff; $1.0 \mathrm{~kg}$ of oilseed rape; $0.5 \mathrm{~kg}$ of steamed oats). In addition, a complex feed supplement was introduced into the animal feeding ration $(0.7 \mathrm{~kg}$ per day), which was consists of grain fermentation products, peat, waste from food production and micronutrients.

The average milk productivity of experimental animals at the beginning of experiment was 28.6 
$\mathrm{kg}$. The average age of dairy at the beginning of experiment was 5 years. The average number of days of milking cows at the start of the experiment was 178 days.

The milk production of each animal was individually assessed during control milking using "DeLaval" milking equipment.

The treatment of experimental animals was carried out in accordance with the European Convention for the Protection of Vertebrate Animals used for Experimental and Other Scientific Purposes (European Treaty Series - No. 123).

\section{Milk Quality and Composition}

Individual milk samples were analyzed for fat and protein contents using "Lactan 1-4" milk quality analyzer ("Sibagropribor", Russia). For milk samples preparation volume of $25 \mathrm{~cm}^{3}$ was heated in a water bath to a temperature of $(45 \pm 5)$ - $\mathrm{C}$ and thoroughly mixed by transfusion from vessel to vessel (at least 3 times). Then the sample was cooled to a temperature of $(22 \pm 4)^{\circ} \mathrm{C}$. The prepared sample was placed in device. After 2.5-3.5 minutes, results were read from the device indicator. After each measurement, the device was washed with water and detergent according to the instructions that came with the device.

Calculation of the energy value of milk obtained from animals was made on the basis of the "Guidelines for hygienic nutrition control in organized groups" (approved by the USSR Ministry of Health on December 29, 1986 No. 4237-86). The energy value of milk was determined by multiplying the content of proteins, fats and carbohydrates $(\mathrm{g} / \mathrm{kg})$ by the corresponding coefficients of their energy value, which were equal to: for proteins $-4 \mathrm{kcal} / \mathrm{g}$, for fats $-9 \mathrm{kcal} / \mathrm{g}$, for carbohydrates $-4 \mathrm{kcal} / \mathrm{g}$. Carbohydrate (lactose) content in milk was determined using infrared analyzer in accordance with GOST 32255-2013 "Milk and dairy products. An express instrumental method for determining the physicochemical identification indicators using an infrared analyzer (with Change No. 1)" at JSC "Elit GPP" in Vysokogorsky Municipal District of Tatarstan Republic.
Calculation of energy value was carried out according to the following formula:

$$
\mathrm{E}=((4 \mathrm{x}(\mathrm{P})+9 \mathrm{x}(\mathrm{F})+4 \mathrm{x}(\mathrm{C})) \mathrm{x} 4184) /
$$
1000000 ,

where:

E - energy value of a milk dish, $\mathrm{MJ} / \mathrm{kg}$;

P, F, C - the amount of proteins, fats and carbohydrates in milk, respectively, g;

4; 9 and 4 are the energy value coefficients of proteins, fats and carbohydrates, respectively, $\mathrm{kcal} / \mathrm{g}$;

4184 - the number of $\mathrm{J}$ per $1 \mathrm{kcal}$;

1000000 - conversion rate $\mathrm{J}$ to $\mathrm{MJ}$. DNA isolation

DNA was extracted from animal blood taken from vena coccygea using a reagent kit "DNASorb-B" (NextBio, Russia) for DNA extraction from the clinical material in accordance with the manufactures recommendation.

\section{Genotyping}

Animal genotypes were determined by the of economically valuable traits genes loci: kappacasein (CSN3), beta-lactoglobulin (LGB), prolactin (PRL), somatotropin (GH), thyroglobulin (TG5). The establishment of animal genotypes was carried out by polymerase chain reaction (PCR), followed by hydrolysis of PCR products. The reaction composition for PCR, consisting of template DNA, dNTPs, Taq polymerase with supplied buffer, was prepared with a total volume of $20 \mu \mathrm{l}$.

For the analysis of the CSN3 gene locus, a set of primers with the following nucleotide sequence was used: F: 5'ATCATTTATGGCCATTCCACCAAAG-3 '(25 n.); R: 5'GCCCATTTCGCCTTCTCTFTAACAGA-3 '(26 n.). To analyze the LGB gene locus, a set of primers with the following nucleotide sequence was used: F: 5'-GTCCTTGTGCTGGACACCGACTACA-3 '(25 n.); R: 5'CAGGACACCGGCTCCCGGTATATGA-3 '(25 n.). To analyze the PRL gene locus, a set of primers 
with the following nucleotide sequence was used: F: 5'-CGAGTCCTTATGAGCTTGATTCTT-3 ', (24 $\mathrm{n}$ ); $\quad \mathrm{R}$ : 5'GCCTTCCAGAAGTCGTTTGTTTTC-3 '(24 n.). For the analysis of the GH gene locus, a set of primers with the following nucleotide sequence was used: F: 5'-GCTGCTCCTGAGGGCCCTTC-3 '(20

n.); $\mathrm{R}$ :

5 -

CATGACCCTCAGGTACGTCTCCG-3 '(23 n.). To analyze the TG5 gene locus, a set of primers with the following nucleotide sequence was used: F: 5'-GGGGATGACTACGAGTATGACTG-3 '(23 n.); GTGAAAATCTTGTGGAGGCTGTA-3 '(23 n).

Amplification was performed under optimal temperature and time conditions for each individual set of oligonucleotide primers on a MyCycler T100 programmable thermal cycler (Bio-Rad Laboratories, USA). The amplification products obtained were digested with restriction enzymes Hinf I, HaeIII, Rsa I, Alu I at $37^{\circ} \mathrm{C}$ for $16 \mathrm{~h}$ for the CSN3, LGB, PRL, GH, and BstX2I genes and at 60

${ }^{\circ} \mathrm{C}$ for the TG5 gene, respectively.
Genotyping was evaluated by running a small aliquot of PCR-RFLP product on $2.6 \%$ agarose gel in the presence of ethidium bromide in 1xTBE buffer at $20 \mathrm{~V} / \mathrm{cm}$ for $30 \mathrm{~min}$. Visualization and results' fixation was carried out using UV transilluminator and Gel Doc documentation system.

\section{Statistical Analysis}

Results are expressed as means \pm standard deviation. The results obtained were processed using mathematical and statistical methods using the Microsoft Excel program.

\section{Results and discussions}

The data obtained shows that changes in milk productivity of dairy cows which were on balanced feeding diet recommended by us depended on the animal's genotype. The maximum increase in cows' productivity in terms of mass fractions of both fat and protein in milk (Figure 1) was 19.7\% (or $6.9 \mathrm{~kg}$ ) and was characteristic to animals with the BB genotype of the PRL gene.

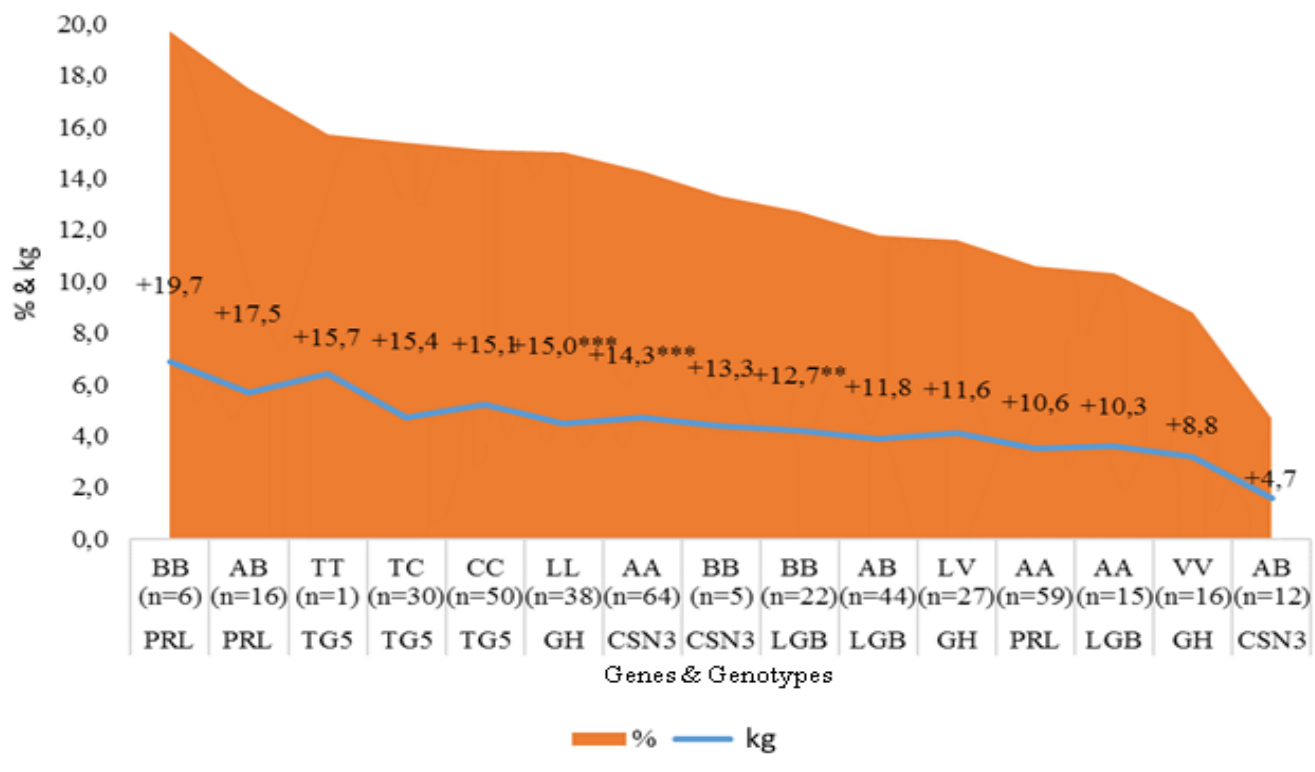

Note: ** $-P<0.01$; *** $-P<0.001$

Figure 1. Changes in milk production of dairy cows in terms of the basis fat and protein mass fraction in milk. 
As to TG5 gene, this change was most pronounced in the dairy cow with TT genotype $15.7 \%$ (or $6.4 \mathrm{~kg}$ ), and slightly smaller but statistically significant - in animals with LL genotype of GH gene - $15.0 \%$ (or $4,5 \mathrm{~kg}, \mathrm{P}<0.001$ ). It is necessary to note that in animals with the AA genotype of CSN3 gene milk production $(14.3 \%$ or $4.7 \mathrm{~kg}$ ) was also $0.7 \%$ lower, and these changes in productivity dynamics were statistically significant $(\mathrm{P}<0.001)$. As to LGB gene, the highest increase in milk productivity was found in animals with the genotype $\mathrm{BB}$, which was $12.7 \%$ (or $4.2 \mathrm{~kg}, \mathrm{P}$ $<0.01)$.

Along with the dynamics of milk productivity, differences due to the influence of genotypes on mass fraction of fat and protein in cow's milk have been established. For example, the largest mass fraction of fat in milk of dairy cows was found in cows with the AA genotype of CSN3 gene (3.73\%). Similar influence of the LGB gene was detected in animals with a homozygous BB genotype (3.79\%). Also, the maximum content of the mass fraction of fat in milk depends on PRL gene in animals with the same genotype was found $(4.03 \%)$, while for $\mathrm{GH}$ gene maximum of the mass fraction of fat in

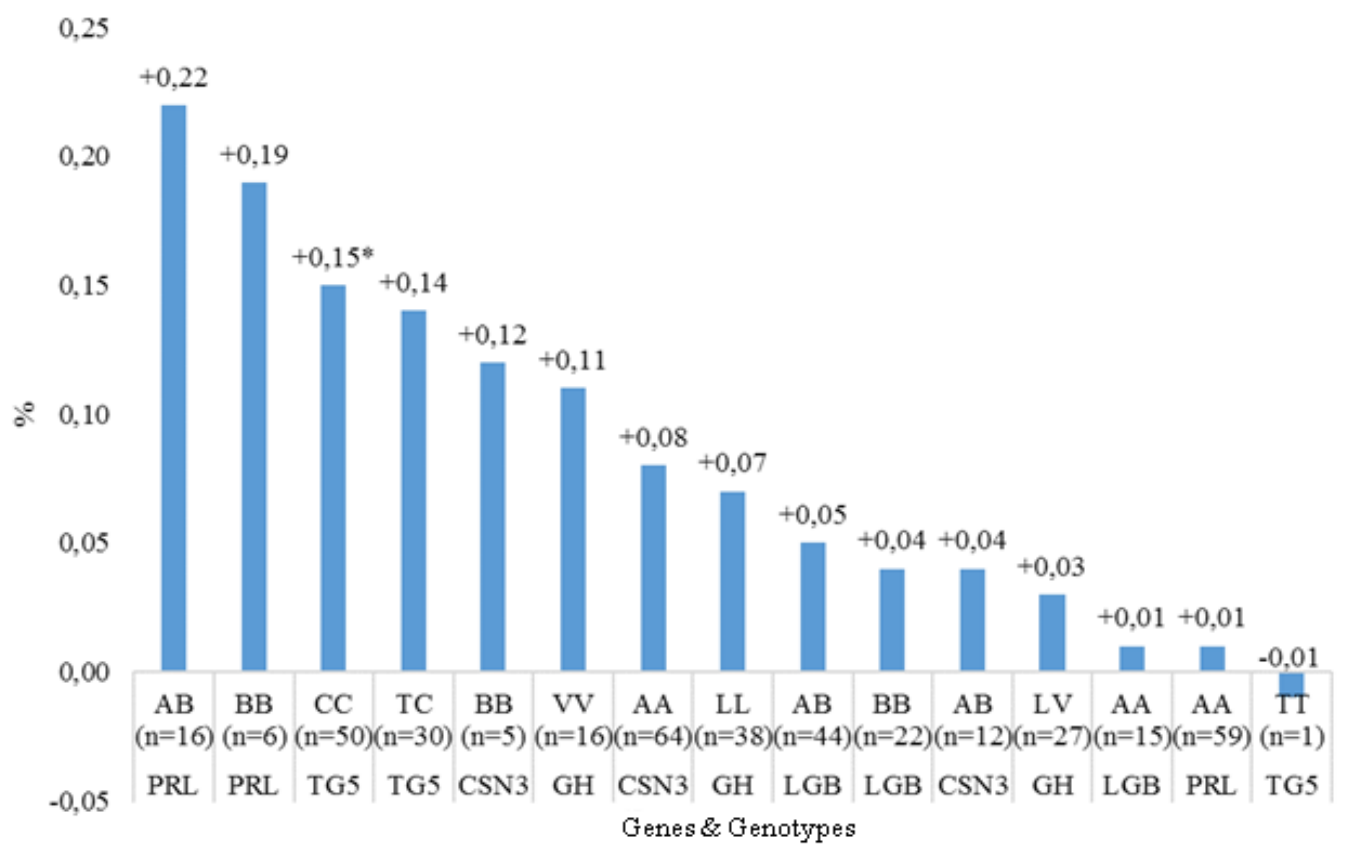

Note: * - P $<0.05$ milk was found in animals with the heterozygous LV genotype $(3.92 \%)$. The highest content of fat mass fraction in milk was characteristic to animals with a homozygous genotype for the TG5 gene $(4.59 \%)$.

Analysis of the content of the mass fraction of protein in the milk of experimental animals dependent on alleles of genes studied showed that in animals with a homozygous AA genotype for the CSN3 gene, the protein content in milk was 3.31\%. In dairy cows with homo and heterozygous genotypes $\mathrm{AA}$ and $\mathrm{AB}$, respectively, of LGB gene, the content of protein mass fraction in milk was $3.27 \%$, as well as in animals with LL and VV genotypes of GH gene. It should be noted that in animals with TT and BB genotypes for TG5 and PRL genes, the content of the protein mass fraction in milk were found to be the highest $-3.35 \%$ and $3.30 \%$ respectively, which repeats the trend in the content of the fat mass fraction in milk.

Data about dynamics of the content of fat mass fraction in milk of dairy cows (Figure 2) shows that, the maximum increase of fat content in milk of animals with the heterozygous genotype $\mathrm{AB}$ of PRL gene was observed $(0.22 \%)$.

Figure 2. Change in the fat mass fraction in milk of dairy cows. 
As to TG5 gene, a significant increase in the content of fat mass fraction in milk was detected in homozygous animals with the $\mathrm{CC}$ genotype, which was $0.15 \%(\mathrm{P}<0.05)$. In cows with a homozygous $\mathrm{BB}$ genotype for the CSN3 gene, the fat content in milk increased by $0.12 \%$, in homozygous animals with a VV genotype of GH gene it increased by $0.11 \%$, and in heterozygous animals with $\mathrm{AB}$ genotype of LGB gene it increased by $0.05 \%$.
However, other than described above significant changes have not been found.

Analyzing the changes in content of the protein mass fraction in milk of dairy cows (Figure 3) it was found that the most significant increase in this indicator was in animals with the homozygous BB genotype of PRL gene, which increased by $0.11 \%$, however, this change was not statistically significant.

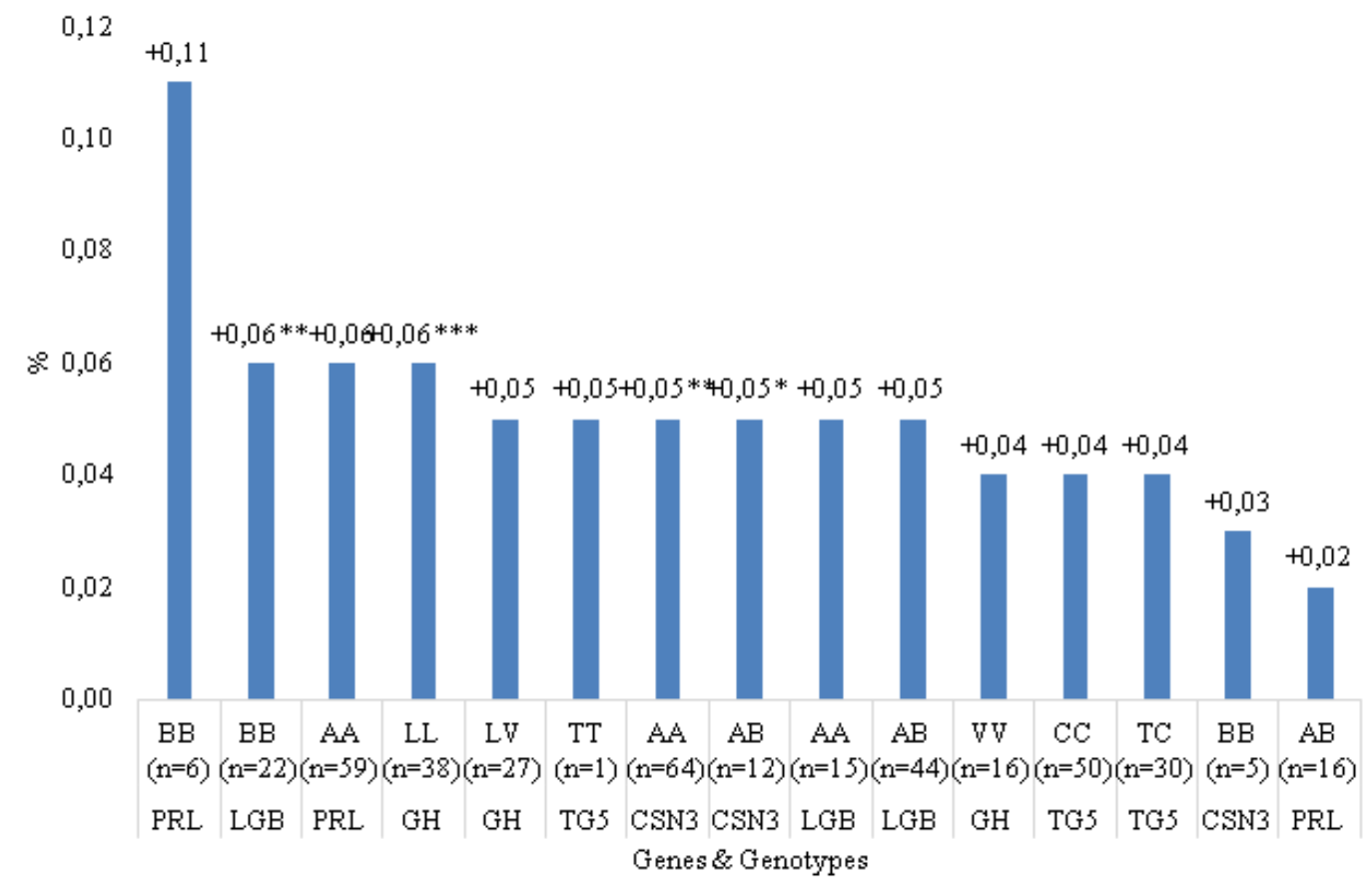

Note: * - P $<0.05 ; * *$ - $\mathrm{P}<0.01$; *** - $\mathrm{P}<0.001$

Figure 3. Change in the protein mass fraction in milk of dairy cows.

A significant increase in milk yield was observed in cows with homozygous BB and LL genotypes of LGB and GH genes too, which were up to $0.06 \%$ with $\mathrm{P}<0.01$ and $\mathrm{P}<0.001$, respectively. In animals with genotypes AA and $\mathrm{AB}$ of $\mathrm{CSN} 3$ gene, an increase in protein mass fraction in milk was $0.05 \%$ with $\mathrm{P}<0.01$ and $\mathrm{P}$ $<0.05$, respectively. The protein content in the milk of cows with a homozygous TT genotype of TG5 $\mathrm{g}$ gene changed to a similar value, however, the obtained increase was not significant.

In general, it should be noted that there was a positive dynamics in the content of fat and protein mass fractions in milk of dairy cows during research period, which was largely determined by the genotype of particular genes.

Obviously, changes in the content of such important indicators as the fat and protein mass fraction in the milk have to affect its energy value (Figure 4). 


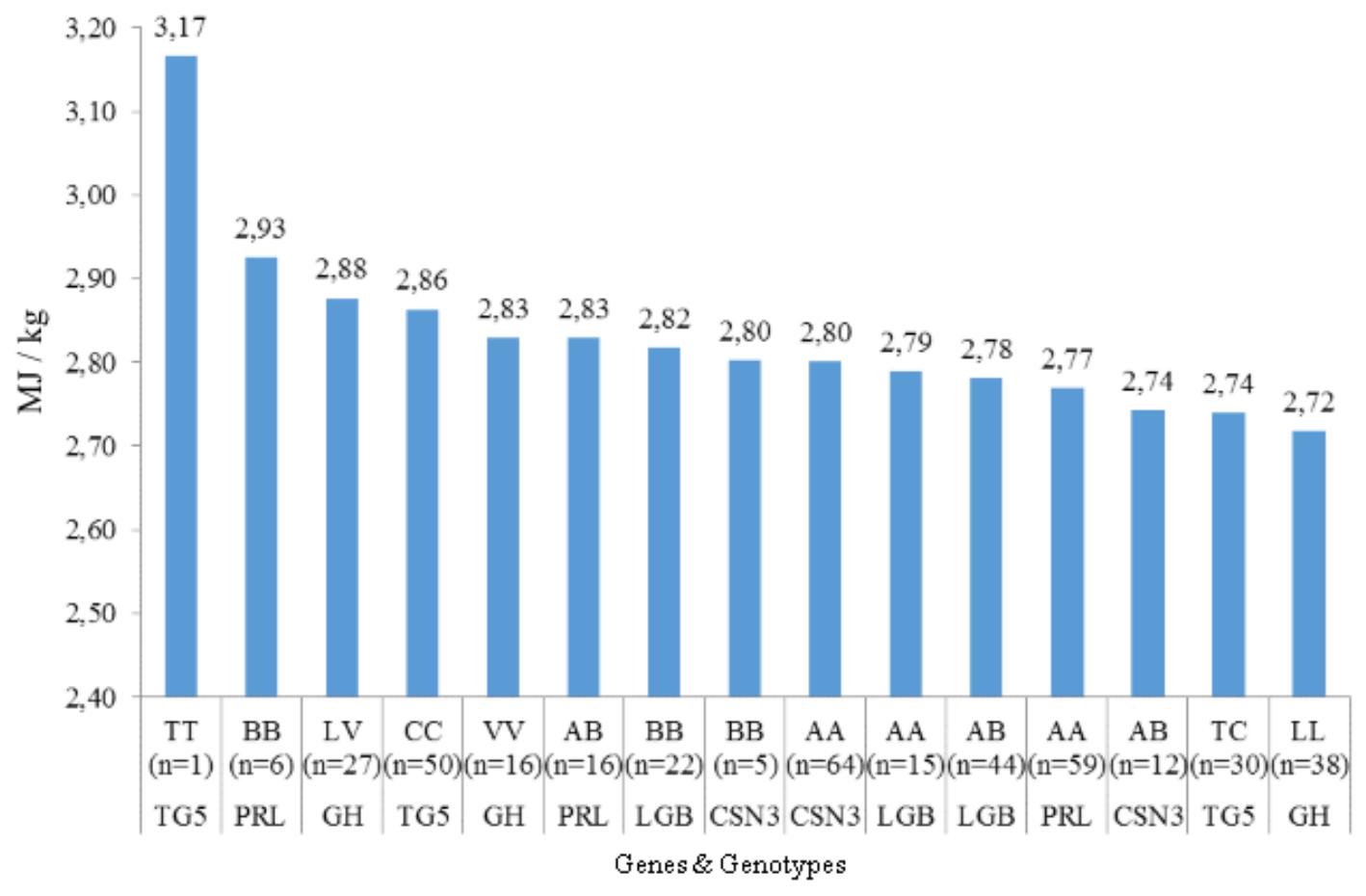

Figure 4. The energy value of milk from dairy cows

In the context of genes studied, as to CSN3 gene, the highest energy value was at milk obtained from animals with homozygous genotypes AA and BB $(2.80 \mathrm{MJ} / \mathrm{kg})$. As to LGB and PRL genes, the highest energy value was found in milk of homozygous cows with BB genotypes (2.82 and $2.93 \mathrm{MJ} / \mathrm{kg}$ ). As to $\mathrm{GH}$ gene, the highest energy value was detected at milk obtained from animals with the heterozygous LV genotype $(2.88 \mathrm{MJ} / \mathrm{kg})$, and as to TG5 gene - at animals with the TT homozygous genotype (3.17 MJ / kg).

\subsection{Discussion}

We found that the highest increase in milk productivity is in dairy cows with a homozygous AA genotype of CSN3 gene and it is in accordance with data obtained by Chasovshchikova with coauthors (Chasovshchikova et al, 2017) in their studies. However, in a population of dairy cows in Hungary, Vági and Baranyi ((Vági \& Baranyi, 2000) revealed that animals with heterozygous genotype $\mathrm{AB}$ show the highest rate in milk production. We suppose that this fact depends on the fact that they used first lactation animals in their studies and it affected on the results obtained (Vági $\&$ Baranyi, 2000).
Also, our data which shows that the presence of the BB genotype of PRL gene in dairy cows determined the highest level of milk productivity in animals that confirms previously obtained data by Nekrasov with coauthors (Nekrasov et al, 2017).

It is necessary to note that $\mathrm{Di}$ Gregorio with coauthors (Di Gregorio et al, 2017) associate allele $\mathrm{B}$ of the LGB gene in general and the BB genotype in particular with the highest values of milk yield, which is fully in accordance with our results with the same level of reliability $(\mathrm{P}<0.01)$. Metin Kiyici with coauthors (Metin Kiyici et al, 2019) considers $\mathrm{GH}$ gene as one of the promising candidates for assessing the potential milk production of dairy cow. In addition, according to Molee with coauthors (Molee et al, 2015), the LGB + GH gene model may be the most suitable for breeding to improve the milk production of cows. Sabour and Lin (Sabour \& Lin, 1996), in turn, found that the V allele of the GH gene was preferable in terms of increasing the milk yield obtained from cows. On the contrary, Shariflou with coauthors (Shariflou et al, 2000) showed greater contribution of $\mathrm{L}$ allele to increase of milk yield in cows. Lucy with coauthors (Lucy et al, 1993) came to the same opinion in relation to the milk productivity of Holstein in 
USA, while the influence of the $\mathrm{V}$ allele was most pronounced in the Jersey cattle breed.

Some other studies showed an increase in milk yield in cows with the LL genotype of the GH gene, but only in animals with the first lactation (Akyuz et al, 2015). On the other hand, Kovács with coauthors (Kovács et al, 2006) and Balogh with coauthors (Balogh et al, 2008) reported a greater contribution of the LV genotype in formation of milk productivity level. It should be noted that the absence of any connection between the genotype and the level of milk productivity was indicated by Hradecka with coauthors (Hradecka et al, 2008), while in our studies, the highest increase in milk productivity was found in animals with the LL genotype of GH gene.

It is interesting to note that, according to Zinnatova and Zinnatov (Zinnatova et al, 2014), the highest milk productivity was detected in animals with the CC genotype of TG5 gene. In our studies, the most increase in milk productivity was characteristic to animals with the TT genotype. However, due to the low frequency of its genotype, these data require additional refinement in further studies.

On the one hand, in a number of articles it was shown that different genotypes of CSN3 and LGB genes have a pronounced effect on the physicochemical milk composition (Schennink et al, 2008; Ozdemir et al, 2018; Neamt et al, 2017). On the other hand, Duifhuis-Rivera with coauthors (Duifhuis-Rivera et al, 2014) and Dogru (Dogru et al, 2015) were unable to confirm the presence of any of correlations mentioned above. At the same time a number of authors (Ozdemir et al, 2018; Van den Berg et al, 1992; Boland, \& Hill, 2001; Wedholm et al, 2006; Heck et al, 2009) found that the $\mathrm{B}$ allele of CSN3 and LGB genes is associated with a higher protein mass fraction in cow milk. However, in our studies, as was reported above, animals with A allele of CSN3 gene (homozygous genotype AA) and LGB gene (homozygous genotype $\mathrm{AA}$ and heterozygous genotype $\mathrm{AB}$ ) has the largest protein mass fraction in milk.

In addition, the presence of the $\mathrm{A}$ allele of CSN3 gene (homozygous AA and heterozygous $\mathrm{AB}$ genotypes) caused the maximum increase in protein mass fraction in milk during the study period, while for the LGB gene the most pronounced dynamics of this indicator was found in animals with $\mathrm{B}$ allele (homozygous genotype BB). Ambiguous data on the effect of PRL alleles on milk composition were obtained by Staiger with coauthors (Staiger et al, 2010), although our data showed that animal carriers of B allele showed not only the maximum protein content in milk, but also its most pronounced increase throughout entire research period. The influence of $\mathrm{GH}$ gene genotype on the protein content in cow's milk was reported by Chung with coauthors (Chung et al, 1996) and Dybus (Dybus, 2002). Moreover, according to their data, animals with homozygous LL genotype were higher in this indicator. We have confirmed the patterns they obtained, but it is it is necessary to note that animals with this genotype were characterized not only by the highest protein content, but also its most pronounced increase during the experiment. In addition, in our studies, dairy cows with VV homozygous genotype were characterized by high protein content. By the opinion of Zinnatova and Zinnatov (Zinnatova et al, 2014), individuals with the CC homozygous genotype of TG5 gene are characterized by higher milk protein production, which contradicts the our data, however, taking into account the low frequency of occurrence of animals with TT homozygous genotype, the results presented by them seemed to be most convincing.

According to results of Neamt with coauthors (Neamt et al, 2017) and Gurses with coauthors (Gurses et al, 2018), dairy cows with the AA genotype of CSN3 gene are characterized by the highest milk fat yield. In our studies, this pattern was confirmed, but, at the same time, we found the greatest influence of the homozygous BB genotype on the intensity of changes in the content of fat mass fraction in milk. In addition, Neamt with coauthors (Neamt et al, 2017) showed that the presence of $\mathrm{AB}$ heterozygous genotype of LGB gene in animals causes the highest fat content in milk of dairy cows, but we found that this genotype mainly affects the intensity of changes in milk fat content, while the highest milk fat content is more characteristic to animals with the homozygous $\mathrm{BB}$ 
genotype. According to Patel and Chauhan (Patel \& Chauhan, 2017), the presence of B alleles of PRL gene in animals can determine their highest milk fat content. In general, our results confirm this statement, however, if the maximum milk fat content was more typical for animals with the homozygous BB genotype, the most pronounced change in level of fat content in milk was for animals with the $\mathrm{AB}$ genotype.

The presence of a significant relationship between the fat content in cow's milk and the genotype of GH gene was reported by Hradecka with coauthors (Hradecka et al, 2008) and Khatami with coauthors (Khatami et al, 2005). We clarified that LV genotype determines only the content of the fat mass fraction in milk and VV genotype determines the intensity of changes in fat mass fraction in it. The homozygous TT genotype of TG5 gene according to Zinnatov with coauthors (Zinnatov et al, 2017) determines the highest milk production of dairy cows, which fact is also confirmed by us. At the same time in animals with $\mathrm{CC}$ homozygous genotype dynamics of fat mass fraction level in milk was found to be more pronounced.

Changes in the energy value of milk as a result of various feed products using and changes in the diet structure were reported in studies of Gafner with coauthors (Gafner et al, 2017). Our data on milk energy value are in accordance with values of this indicator established by these authors in general. Changes in the milk energy value in the context of polymorphism of genes of economically valuable traits was reported in a study by Safina (Safina, 2018), however, currently it is not possible to evaluate results obtained because of the difference in the set of marker genes studied, so additional study of this issue is required.

\section{Conclusions}

So, based on the data obtained we can conclude that the dynamics of milk production of dairy cows is for the most part determined by the alleles of the genes of economically valuable traits. The presence of B allele and especially BB homozygous genotype of PRL gene in studied population caused a maximum increase in their milk productivity up to $19.7 \%$, however, this result was not reliable, and therefore it requires further investigation. The maximum statistically significant increase in dairy cows' productivity was found $(15.0 \%, \mathrm{P}<0.001)$ was found in the presence of the L allele of GH gene and at homozygous LL genotype with balanced feeding. Statistically significant increase in milk productivity were also observed in animal which have alleles $\mathrm{A}$ and $\mathrm{B}$ with homozygous genotypes $\mathrm{AA}$ and $\mathrm{BB}$ for the $\mathrm{CSN} 3$ and $\mathrm{LGB}$ genes, respectively.

The maximum increase in the fat mass fraction in milk $(0.22 \%)$ was found in animals with the $\mathrm{AB}$ genotype for the PRL gene, while the statistically significant increase in milk fat content depends on the presence of the $\mathrm{C}$ allele and the $\mathrm{CC}$ homozygous genotype of TG5 gene $(0.15 \%, \mathrm{P}<0.05)$. The maximum increase in the protein mass fraction in milk in animals with the $\mathrm{B}$ allele and the $\mathrm{BB}$ homozygous genotype for the PRL gene was observed, which was to $0.11 \%$. However, this change was not statistically significant. The maximum statistically significant increase in milk yield was found in dairy cows with $\mathrm{B}$ and $\mathrm{L}$ alleles and homozygous BB and LL genotypes for LGB and $\mathrm{GH}$ genes, which were up to $0.06 \%$ with $\mathrm{P}$ $<0.01$ and $\mathrm{P}<0.001$, respectively.

Analysis of milks' energy value showed that A and $\mathrm{B}$ alleles and homozygous genotypes $\mathrm{AA}$ and $\mathrm{BB}$ of CSN3 gene and homozygous BB genotypes of LGB and PRL genes, as well as the T allele and TT homozygous genotype of TG5 gene, are associated with milk production with highest energy value, while as to GH gene it was found that this indicator was the highest in animals with heterozygous LV genotype. However, due to the lack of statistically significant changes in the energy value of milk, the data obtained required further clarification.

\section{References}

Akyuz, B., Agaoglu, O.K., Akcay, A., \& Agaoglu, A.R. (2015) Effects of DGAT1 and GH1 polymorphism on milk yield in Holstein cows reared in Turkey. Slovenian Veterinary Research, 52, 185 - 191. 
Balogh, O., Szepes, O., Kovacs, K., Kulcsar, M., Reiczigel, J., Alcazar, J.A., Keresztes, M., Febel, H., Bartyik, J., Fekete, S.Gy., Fesus, L., \& Huszenicza, Gy. (2008) Interrelationships of growth hormone AluI polymorphism, insulin resistance, milk production and reproductive performance in Holstein-Friesian cows. Veterinarni Medicina, 53(11), $604-616$.

Boland, M., \& Hill, J. (2001) Genetic selection to increase cheese yield: The Kaikoura experience. Australian Journal of Dairy Technology, 56, 171 - 176.

Chasovshchikova, M.A., Sheveleva, O.M., Svjazhenina, M.A., Tatarkina, N.I., Satkeeva, A.B., Bakharev, A.A., Ponomareva, E.A., \& Koshchaev, A.G. (2017) Relationship between the genetic variants of kappa-casein and prolactin and the productive-biological characteristics of cows of the black-motley breed. Journal of Pharmaceutical Sciences and Research, 9(7), 1038 - 1044.

Chilliard, Y., Glasser, F., Ferlay, A., Bernard, L., Rouel J., \& Doreau, M. (2007) Diet, rumen biohydrogenation and nutritional quality of cow and goat milk fat. European Journal of Lipid Science and Technology, 109, 828 - 855.

Chung, E.R. Rhim T.J., \& Han S.K. (1996) Associations between PCR-RFLP markers of $\mathrm{GH}$ and PRL genes and production traits. Korean Journal of Animal Science, 38, 321 336.

Di Gregorio, P., Di Grigoli, A., Di Trana, A., Alabiso, M., Maniaci, G., Rando, A., Valluzzi, C., Finizio, D., \& Bonanno, A. (2017) Effects of different genotypes at the CSN3 and LGB loci on milk and cheese-making characteristics of the bovine cinisara breed. International Dairy Journal, 71, 1 - 5.

Dogru, U. (2015) $\beta$-Lactoglobulin genetic variants in Brown Swiss dairy cattle and their association with milk yield and quality traits. Journal of Animal and Plant Sciences, 25(2), $595-598$.

Duifhuis-Rivera, Lemus-Flores T. C., AyalaValdovinos M. Á., Sánchez -Chiprés D. R., Galindo-García J., Mejía-Martínez K. \& González-Covarrubias E. (2014)
Polymorphisms in beta and kappa casein are not associated with milk production in two highly technified populations of Holstein cattle in México. Journal of Animal and Plant Sciences, 24(5), $1316-1321$.

Dybus, A. (2002) Associations between Leu/Val polymorphism of growth hormone gene and milk production traits in Black and White cattle. Archiv fur Tierzucht, 45, $421-428$.

Dybus, A., Swatowska I., Czerniawska-Piatkowska E., Grzesiak W., Wojcik J., Rzewucka E., \& Zych, S. (2004) PIT1-HinfI gene polymorphism and its association with milk production traits in polish Black and White cattle. Archiv fur Tierzucht, 6, $557-563$.

Furaeva N.S. (2013) Current state of pedigree base of a cattle of the Yaroslavl breed and prospect of its development. Herald of Agroindustrial complex of Upper Volga region, (1(21)), 21 30. (in Russian).

Gafner, V.D., Gorelik, O.V., \& Bykova, O.A. (2017). Milk yields and quality obtained from cows fed rations supplemented with triticale. News of the Orenburg State Agrarian University, (4 (66)), 171 - 174. (in Russian).

Giniyatullin Sh.Sh. (2016) Cow feeding according to lactation periods and measures to increase milk yields. Russian electronic scientific journal, (1(19)), 263 - 279. (in Russian).

Gurses, M., Yuce, H. Onalan Etem, E. \& Patir, B. (2018). Polymorphisms of kappa-casein gene and their effects on milk production traits in Holstein, Jersey and Brown Swiss cattle. Animal Production Science, 58, 778 - 784.

Heck, J.M.L., Schennink A., Valenberg H.J.F., Bovenhuis H., Visker M.H.P.W., van Arendonk J.A.M., \& van Hooijdonk A.C.M. (2009) Effects of milk protein variants on the protein composition of bovine milk. Journal of Dairy Science, 92, 1192 - 1202.

Hradecka, E., Citek, J., Panicke, L., Rehout, V., \& Hanusova, L. (2008) The relation of GH1, GHR and DGAT1 polymorphisms with estimated breeding values for milk production traits of German Holstein sires. Czech Journal of Animal Science, 53, 238 - 245. 
Khatami S. R., Lazebny O. E., Maksimenko V. F., Sulimova G. E. (2005) Association of DNA polymorphisms of the growth hormone and prolactin genes with milk productivity in Yaroslavl and Black-and-White cattle. Russian Journal of Genetics, 41(2), 167-173.

Kovács, K., Völgyi-Csík J., Zsolnai A., Györkös I., \& Fésüs L. (2006) Associations between the AluI polymorphism of growth hormone gene and production and reproduction traits in a hungarian holstein-friesian bull dam population. Archives Animal Breeding, 49(3): $236-249$.

Lucy, M.C. Hauser, S.D., Eppard, P.J., Krivi, G.G., Clark, J.H., Bauman, D.E., \& Collier, R.J. (1993) Variants of somatotropin in cattle: gene frequencies in mayor dairy breeds and associated milk production. Domestic Animal Endocrinology, 10, 325 - 333.

Maslyuk, A.N., \& Tokareva, M.A. (2018). Optimization efficiency of protein and carbohydrate nutrition of highly productive cows. Animal Husbandry and Fodder Production, 101(4), 164-171. (in Russian).

Metin Kiyici, J., Arslan, K., Akyuz, B., Kaliber, M., Akse,1 E.G., \& Çinar, M.U. (2019) Relationships between polymorphisms of growth hormone, leptin and myogenic factor 5 genes with some milk yield traits in holstein dairy cows. International Journal of Dairy Technology, 72(1), $1-7$.

Molee, A., Poompramun, C., \& Mernkrathoke, P. (2015) Effect of casein genes - beta-LGB, DGAT1, GH, and LHR - on milk production and milk composition traits in crossbred Holsteins. Genetics and Molecular Research, 14(1), $2561-2571$.

Neamt, R.I. Saplacan G., Acatincai S., Cziszter LT., Gavojdian D., \& Ilie D.E. (2017) The influence of CSN3 and LGB polymorphism on milk production and chemical composition in Romanian Simmental cattle. Acta Biochimica Polonica, 64(3), 493 - 497.

Nekrasov, D.K. Kolganov, A.E., Kalashnikova, L.A., \& Semashkin, A.V. (2017) The relationship of polymorphic variants of genes of the prolactin, growth hormone and kappa- casein with milk productivity of Yaroslavl breed cattle. Agrarnyj vestnik Verhnevolzh'ja. [Agrarian Journal of the Upper Volga Region], (1(18)), 40-48 (in Russian).

Ozdemir, M,. Kopuzlu, S., Topal, M., \& Bilgin O.C. (2018) Relationships between milk protein polymorphisms and production traits in cattle: a systematic review and meta-analysis. Archives Animal Breeding, 61(2), 197 - 206.

Patel, J.B. \& Chauhan , J.B. (2017) Polymorphism of the prolactin gene and its relationship with milk production in gir and kankrej cattle. Journal of Natural Science, Biology and Medicine, 8, $167-170$.

Perišić, P., Skalicki, Z., \& Bogdanović, V. (2011).The state in the sector of milk production in European Union and in our country. Biotechnology in Animal Husbandry, 27(3), 315-327.

Sabour, M.P., \& Lin, C.Y. (1996) Association of bGH genetic variants with milk production traits in Holstein cattle. Animal Genetics, 27(Suppl.2), 105.

Safina, N. (2018). Characterization of biological efficiency and full value of milk productivity in holstein heifers with different leptin (LEP) genotypes. Vestnik of Kursk State Agricultural Academy, (4), 131 - 134. (in Russian).

Schennink, A., Heck J.M.L., Bovenhuis H., Visker M.H.P.W., van Valenberg H.J.F., \& van Arendonk J.A.M. (2008) Milk fatty acid unsaturation: Genetic parameters and effects of stearoyl-CoA desaturase (SCD1) and acyl CoA: diacylglycerol acyltransferase 1 (DGAT1). Journal of Dairy Science, 91, 2135 $-2143$.

Shariflou, M.R., Moran, C., \& Nicholas F.W. (2000) Association of Leu127 variant of the bovine growth hormone (bGH) gene with increased yield of milk, fat, and protein in Australian Holstein Friesians. Australian Journal of Agricultural Research, 51, 515 522.

Singh, U., Deb, R., Alyethodi, R. R., Alex, R., Kumar, S., Chakraborty, S., Dhama, K., \& Sharma, A. (2014). Molecular markers and their applications in cattle genetic research: A 
review. Biomarkers and Genomic Medicine, 6(2), 49-58.

Staiger, E.A. Thonney M.L., Buchanan J.W., Rogers E.R., Oltenacu P.A., \& Mateescu R.G. (2010) Effect of prolactin, $\beta$-lactoglobulin, and $\kappa$-casein genotype on milk yield in East Friesian sheep. Journal of Dairy Science, 93(4), $1736-1742$.

Turenkova E., \& Vasilieva O. (2014) Feeding is a key factor for long productive life of a dairy cow. Farm Animals, (2(6)), 98 - 108.

Vági, J., \& Baranyi, M. (2000) Association between milk protein genotypes and milk production and fertility in Hungarian Holstein Friesian, Hungarian Flekvieh and Hungarofries herds. Állattenyésztés és Takarmányozás, 49, $107-119$.

Van den Berg, G., Escher J.T.M., De Koning P.J., \& Bovenhuis H. (1992) Genetic polymorphism of $\kappa$-casein and $\beta$-lactoglobulin in relation to milk composition and processing properties. Nederlands melk en Zuiveltijdschrift, 46, 145 168.

Viale, E., Tiezzi, F., Maretto, F., De Marchi, M., Penasa, M., \& Cassandro, M. (2017). Association of candidate gene polymorphisms with milk technological traits, yield, composition, and somatic cell score in Italian Holstein-Friesian sires. Journal of Dairy Science, 100(9): 7271-7281.

Wedholm, A., Larsen, L.B., Lindmark-Månsson, H., Karlsson, A.H., \& Andrén A. (2006) Effect of protein composition on the cheesemaking properties of milk from individual dairy cows. Journal of Dairy Science, 89: 3296 - 3305.

Zhang L.P., Gan Q.F., Hou G.Y., Gao H.J., Li J.Y. \& Xu S.Z. (2015) Investigation of TG gene variants and their effects on growth, carcass composition, and meat quality traits in Chinese steers. Genetics and Molecular Research, 14 (2): 5320-5326

Zinnatov F.F., Shamsova A.R., Zinnatova F.F., Akhmetov T.M, \& Safiullina A.R. (2017). Interrelation of polymorphism of lipid metabolism genes (LEP, TG5) with milk production of cattle. Scientific notes of Kazan
State Academy of Veterinary Medicine named after N.E. Bauman, 231 (3): 72 - 75. (in Russian).

Zinnatova, F.F., \& Zinnatov, F.F. (2014) Role of lipid metabolism genes (DGAT1, TG5) in improving economically valuable traits cattle. Scientific notes of Kazan State Academy of Veterinary Medicine named after N.E. Bauman, 219(3): 164 - 168. (in Russian).

\section{Acknowledgment}

The work is a part of a state assignment: "Mobilizing the genetic resources of plants and animals, creating innovations that ensure the production of biologically valuable food products with maximum safety for human health and the environment". Registration number: AAAA-A18118031390148-1. 